\title{
Energy-Exergy and Cost Analyses of Solar Tower Systems with Various Capacities for Mersin Province
}

\author{
Elif TURNA DILSEL ${ }^{1}$, Bengi GÖZMEN ŞANLI*1 \\ ${ }^{1}$ Mersin University, Faculty of Engineering, Department of Mechanical Engineering, Mersin
}

Geliş tarihi: 01.04.2021 Kabul tarihi: 13.09.2021

\begin{abstract}
In present study, technical performance and cost of the solar tower system with the capacities of 10 and 20 MW for Mut district of Mersin were investigated. The solar tower systems with various capacities weredesigned by using SAM (System Advisor Model) program theoretically. For SAM program analysis, TMY3 solar radiation data of Mut district of Mersin located at the coordinates of $33.4^{\circ} \mathrm{E} 36.7^{\circ} \mathrm{N}$ was used. For the capacities of 10 and $20 \mathrm{MW}$, the energy generated by this system was determined and the cost of solar tower system was calculated for this system with the capacity of 10 and $20 \mathrm{MW}$, the number of heliostats was determined as 580 and 1115 , respectively and the layout plan of heliostat was generated. Moreover, the first law and the second law of thermodynamic were applied. Energy and exergy efficiencies were determined.
\end{abstract}

Keywords: Solar power towers, System Advisor Model (SAM), Energy

\section{Mersin Mut İlçesi için Farklı Kapasiteli Güneş Kuleleri Enerji Ekserji Analizi ve Maliyet Analizi}

Öz

$\mathrm{Bu}$ çalışmada Mersin'in Mut ilçesine ait 10 ve $20 \mathrm{MW}$ kapasiteli güneş kulesi sisteminin teknik performansı ve maliyeti incelenmiştir. Çeşitli kapasitelerdeki güneş kulesi sistemleri teorik olarak SAM (System Advisor Model) programı kullanılarak tasarlanmıştır. SAM program analizi için Mersin ili Mut ilçesine ait $33.4^{\circ} \mathrm{D} 36.7^{\circ} \mathrm{K}$ koordinatlarında bulunan TMY3 güneş radyasyonu verileri kullanılmıştır. 10 ve 20 MW kapasiteler için bu sistemin ürettiği enerji belirlenmiş ve 10 ve 20 MW kapasiteli bu sistem için güneş kulesi sisteminin maliyeti hesaplanmış, heliostat sayısı sırasıyla 580 ve 1115 olarak belirlenerek yerleşim planı oluşturulmuştur. Ayrıca, termodinamiğin birinci yasası ve ikinci yasası uygulanarak, enerji ve ekserji verimlilikleri belirlenmiştir.

Anahtar Kelimeler: Güneş kulesi sistemleri, (SAM), Enerji

*Sorumlu yazar (Corresponding author): Bengi GÖZMEN ŞANLI, bengigozmen@mersin.edu.tr 


\section{INTRODUCTION}

Solar energy is one of the preferable energy sources and new methods are developed to use solar energy day by day. The solar energy is widely used in engineering application from calculator to electrical power production. Solar tower system is one of the electric energy generation systems. At the solar tower systems, thermal energy is converted to electrical energy by concentrating the sun's rays to the receiver mounted on the top of the tower. A solar tower system consists of heliostats and receiever. The energy generated by the sun's rays coming to the receiver is absorbed by the working fluid used in the system. By the steam in the steam power cycle, the electrical energy production is provided [1].

With this study, it is aimed to evaluate solar tower systems as an alternative method in order to effectively use the solar potential of Mersin region located in the first generation of the solar map. Technical performance and cost of the solar tower system with the capacities of 10 and $20 \mathrm{MW}$ for Mut district of Mersin were investigated. The solar tower systems with various capacities were designed by using SAM (System Advisor Model) program theoretically. For SAM program analysis, TMY3 solar radiation data of Mut district of Mersin located at the coordinates of $33.4^{\circ} \mathrm{E} 36.7^{\circ}$ $\mathrm{N}$, which is taken from METEONORM, was used. And technical performance data was obtained from SAM pogram by using data taken from METEONORM and the cost of the solar tower system was calculated. Correspondingly, energy and exergy analyses were performed.

\section{PREVIOUS STUDIES}

Nowadays, studies on the solar tower systems increase owing to many advantages of these systems. Üçgül et al. [2] performed an investigation on electrical power generation for the university of Süleyman Demirel by designing solar tower systems with capacity of $2 \mathrm{MW}$. The layout plan of heliostat was determined. Furthermore, energy and exergy analyses were done. Another solar tower design, technical and cost analysis study were done by Selbaş et al. [3]. Grasse [4] studied on the solar tower systems with capacity of $30 \mathrm{MW}$ in order to commodify. For 30 years operating times, cost analysis was performed and price of electricity was calculated. Gottschalk et al. [5] designed solar tower systems with capacity of 100MW for various countries like China, Germany and Mediterranean countries. Hekim [6] designed a solar tower system having the capacity of 10 MW with SAM program for Birecik district of Urfa. Moreover, the technical performance of the system and efficiency of the system were assessed. An other study on the solar tower system was carried by Agan et al. [7]. A solar tower system with the capacity of $10 \mathrm{MW}$ for Ceylanpinar district was designed by using with SAM (System Advisor Model) program. The amount of energy production, number of heliostats, heliostat placement and the cost of the system were obtained. In Adiyaman's study [8] , she modeled the receiver of the solar tower system by considering the receivers with external pipes used in solar towers and she compared the results in the literature with the ANSYS Fluent program and verified the model. As a result of the analysis, a new buyer model has been designed to reduce losses. Papagorgiou [9] studied on the efficiency of a solar tower system. In the analysis of the system, the system efficiency is considered to be $80 \%$, the effect of its main dimensions, working coefficients and collector input conditions on the system have been examined. Xu et al. [10] modeled a solar tower system using molten salt as heat transfer fluid. They performed energy-exergy analyses of the system theoretically. The reasons of loss of the solar tower systems were revealed. Yang et al. [11] investigated the interaction of performance of molten salt receiver and efficiency of the system. To increase heat transfer, many experiments were done by using the receivers having straight tube and spiral tube.

\section{MATERIAL AND METHOD}

In present study, meteorological datas of Mut district of Mersin province have been used due to having high solar energy potential and suitable geographical conditions. The average annual 
sunshine duration of this region is about 8.27 hours. Mut has a warm climate with an average annual temperature of $18.1{ }^{\circ} \mathrm{C}$ and the average annual rainfall is about $758 \mathrm{~mm}$. The warmest month of the year is July with an average annual temperature of $30.7{ }^{\circ} \mathrm{C}$ and the coldest month of the year is January [12].The annual global solar radiation or solar radiation map of Mut district and the solar energy potential are shown in Figure 1 [13].

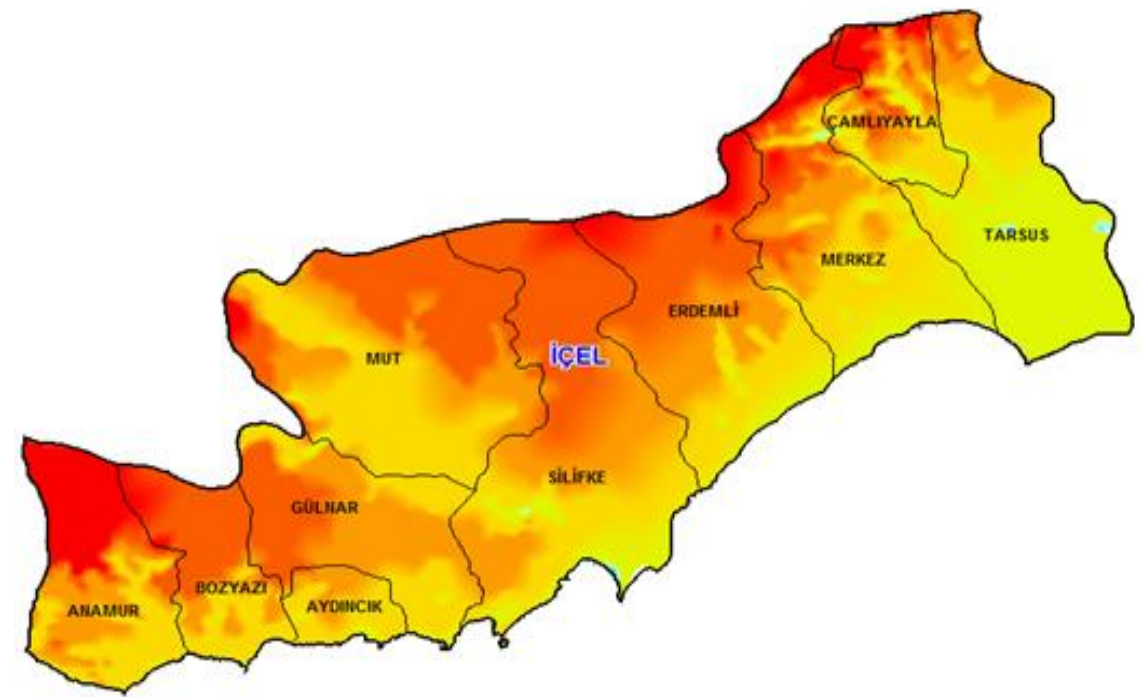

Figure 1. Solar map of Mersin province [13]

\subsection{Solar Tower Systems}

Nowadays, new methods are developed to provide energy production by utilizing solar energy. The solar tower system is one of these new methods. The solar tower systems have been used in Russia, Italy, Spain, Japan, France and the United States since 1980s. Solar tower systems consist of a tower where the receiver is located on and mirrors positioned around the tower to reflect the sun's rays [14].

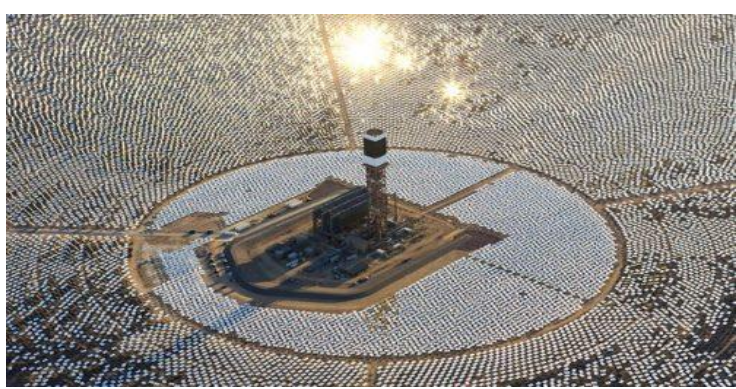

Figure 2. The schematic representation of a solar tower system [15]
Solar tower systems have been used widely in various parts of the world due to the advantages. These advantages can be listed as follows [16]:

- Solar tower systems are safe. Since the system has a simple structure, the probability of failure is less compared to other systems and it is operated at lower cost.

- Solar tower systems do not need the cooling water to provide energy production contrary to many energy generation systems.

- Solar tower systems can generate energy at night by collecting sunlight in the receiver without the need for direct sunlight, compared to other solar energy systems.

- The materials required for the installation of solar tower systems are simple and easily available.

- This system is are easily applicable systems in every region owing to the fact that there is no need for high technology for installation. 


\subsubsection{Elements of Solar Tower Systems Receiver}

Receiver is the element located at the top of a high tower and the sun's rays are concentrated on the receiver by using heliostats. Figure 3 demonstrates an example of receiver. It can be said that the receiver is a kind of heat exchanger that converts sun's rays to the heat energy [6-17].The receivers are exposed to direct or indirect sunlight depending on the structure and type of the materials used during the energy transfer to the working fluid [18]. In order to minimize solar radiation losses, the receivers behave in the form of a black body and centrally combine all the sun rays focused by the heliostats in large heliostat fields.

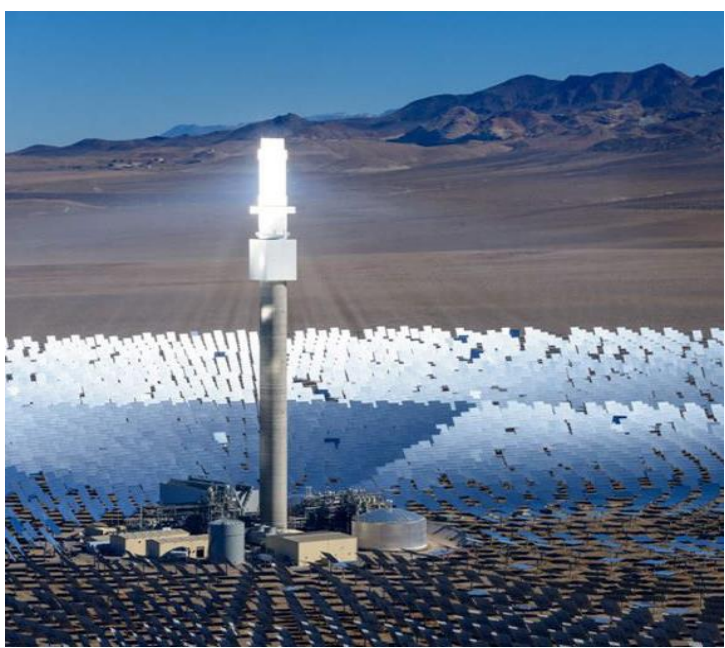

Figure 3. Receiver [19]

\section{Heliostat}

In solar tower systems, tracking mirrors that focus sunlight on the receiver to concentrate it are called heliostats. Heliostats are a kind of two-dimensional mirrors tracking the sun's rays by an open loop control system. They are preferred to reflect and concentrate the sun's rays to the central receiver [18]. The heliostats shown in Figure 4, which are the most basic parts of solar tower systems, consist of the heliostat frame, heliostat arm and heliostat foot and move in two ways, spherical and local during sun tracking [20-21].

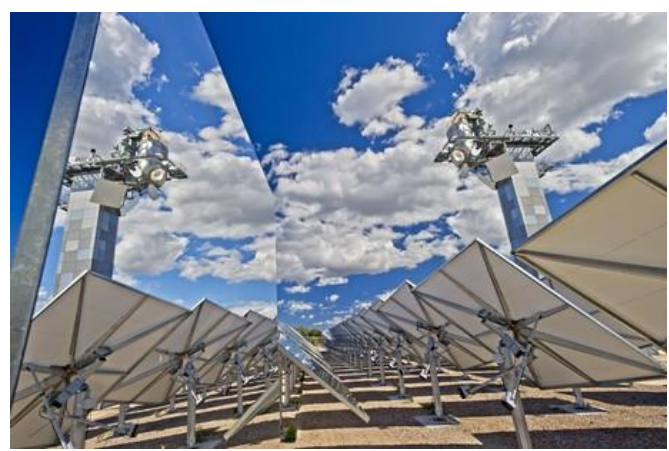

Figure 4. Heliostat [22]

\subsection{Operation Principle of Solar Tower Systems}

In the solar tower systems, thermal energy is converted into electrical energy by concentrating the sun's rays to the receiver mounted on the top of the tower. In these systems, there are many solar tracking mirrors called heliostats in order to reflect the rays coming from the sun by concentrating and focus them on the receiver [23]. The working fluid used in the system absorbs the energy generated by the sun's rays coming to the receiver. The energy generated by the sun's rays coming to the receiver is absorbed by the working fluid used in the system. The molten salt is used as the working fluid in the Rankine cycle. The molten salt embodies the heat long time [14-24]. In the solar tower system, the liguid molten salt at the temperature of $290{ }^{\circ} \mathrm{C}$ is pumped from cold tank to the receiver and the molten salt is heated to the temperature of $565^{\circ} \mathrm{C}$ and it is sent to the hot tank. Then, the heated molten salt is pumped to the steam generation system at the Rankine cycle. After the molten salt in the steam generator returns the cold tank, the storage of it is provided [25]. Operation Principle of Solar tower systems is given in Figure 5 [26].

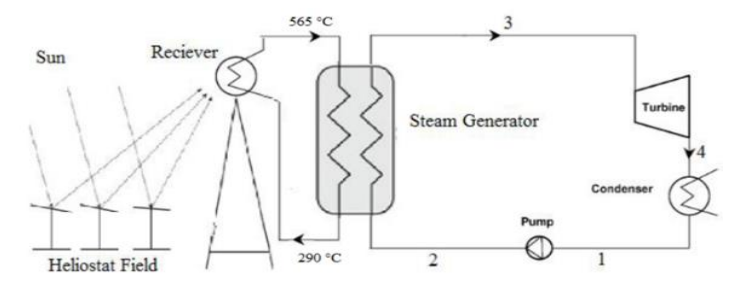

Figure 5. Operation principle of solar tower systems 


\subsection{Thermodynamic Analysis of Solar Tower Systems}

The solar tower systems convert solar power into electrical energy by using Rankine cycle. The Figure 6 indicates the schematic diagram of Rankine cycle and chart of T-S. The elements of cycle are pump, evaporator, turbine and condenser. The cycle starts with pumping of the working fluid to the evaporator and then the heat transfer occurs at the constant pressure. By means of heat transfer, the working fluid becomes superheated vapor and this superheated vapor is sent to the turbine and the pressure is decreased. The mechanic power which is obtained rotating shaft is converted into the electrical energy by connecting generator to the shaft. At the condenser, the heat is transfered to the energy well at the low temperature and low pressure. The cycle is completed by sending the compressed fluid to the pump [27].

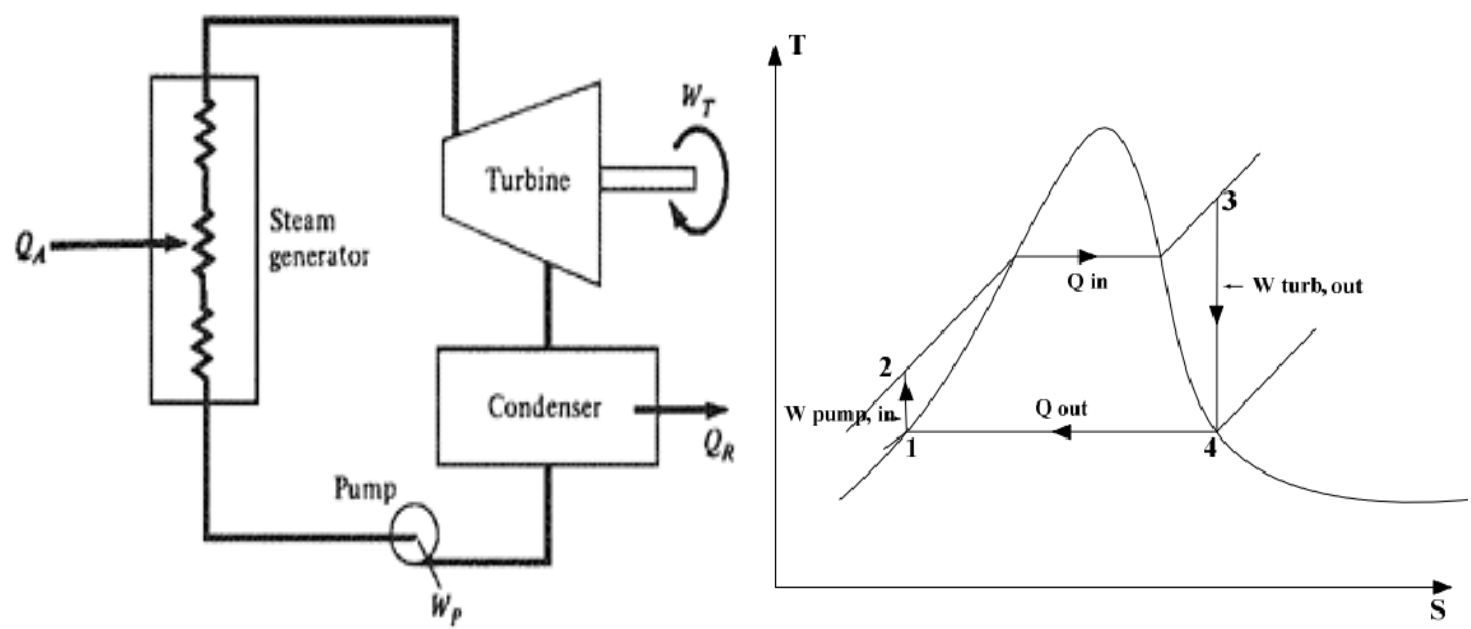

Figure 6. The schematic diagram of Rankine cycle and chart of T-S

The internal energy is constant since the Rankine cycle is a closed-loop system. By using the energy conservation equation, the equation 1 is obtained and this equation means that net work equals to net heat transfer and the net work can be calculated by using the equation 2 [27].

$$
\begin{aligned}
& W_{n, \text { out }}=Q_{\text {in }}-Q_{\text {out }} \\
& W_{n, \text { out }}=W_{\text {out }}-W_{\text {in }}
\end{aligned}
$$

Thermal efficiency is defined as the conversion ratio of net work into heat input as shown below [27].

$\eta_{T}=\frac{W_{n, o u t}}{Q_{\text {in }}}=1-\frac{Q_{\text {out }}}{Q_{\text {in }}}$
The heat transfered to the working fluid at the evaporator can be indicated as [27].

$Q_{i n}=\dot{m}\left(h_{3}-h_{2}\right)$

The shaft power generated by turbine can be defined at the equation 5 . The isentropic efficiency of turbine is expressed with the equation 6 [27].

$W_{\text {out }}=\dot{m}\left(h_{3}-h_{4}\right)$

$\eta_{t}=\frac{h_{3}-h_{4}}{h_{3}-h_{4 s}}$

The discharged heat to the environment is defined with the equation 7 . The spent work at the pump and pump efficiency are calculated by using the Equtions 8 and 9, respectively [27]. 
Energy-Exergy Analyses and Cost Analyses of Solar Tower Systems with Various Capacities for Mut, Mersin Province

$$
\begin{aligned}
& Q_{\text {out }}=\dot{m}\left(h_{4}-h_{1}\right) \\
& W_{\text {in }}=\dot{m}\left(h_{2}-h_{1}\right) \\
& \eta_{\mathrm{p}}=\frac{\mathrm{h}_{2 \mathrm{~s}}-\mathrm{h}_{1}}{\mathrm{~h}_{2}-\mathrm{h}_{1}}
\end{aligned}
$$

For calculation of total efficiency of the system, electrical energy actuating the pump, efficiency of electrical motors of water pump, fan and generator efficiency are important parameters and total efficiency is defined as the ratio of the generated electrical energy to the heat input into the working fluid [28].

At the solar tower systems, exergy balance is presented with the equation 10 and exergy calculations are performed by reading the thermodynamic properties for the each point of the cycle and using the equations below [28].

$$
\dot{E}_{\text {in }}=\dot{E}_{\text {out }}+\dot{E}_{\text {loss }}
$$

Total exergy at the unit of time is shown with " $E$ " and it is computed by using the Equation 11 [29].

$$
\dot{E}=\dot{m} \psi
$$

The flow exergy is explained with the equation of 12. At this equation, $\mathrm{T}_{0}$ means dead state temperature [29].

$\psi=\left(\mathrm{h}-\mathrm{h}_{0}\right)-\mathrm{T}_{\mathrm{o}}\left(\mathrm{s}-\mathrm{s}_{\mathrm{o}}\right) \frac{\mathrm{V}^{2}}{2}+\mathrm{gz}$

The equation 13 represents the calculation of the reversible work of system [29].

$\dot{W}_{\text {reversible }}=\dot{m}\left(\psi_{2}-\psi_{1}\right)$

The reversible work of turbine is defined as shown with the equation 14 while the turbine efficiency is computed by using the equation 15 [29].

$\dot{W}_{t, r e v}=\dot{W}_{t}+\dot{W}_{t, l o s s}$

$$
\varepsilon_{t}=\frac{\dot{W}_{t}}{\dot{W}_{t, r e v}}
$$

For the pump, the equations 16 and 17 are used to calculate the reversible work and pump efficiency, respevtively [29].

$\dot{W}_{p, r e v}=\dot{W}_{p}-\dot{W}_{p, l o s s}$

$\varepsilon_{p}=\frac{\dot{W}_{p, r e v}}{\dot{W}_{p}}$

The loss exergy and exergy efficiency can be calculated by using the equations 18 and 19 , respectively [29].

$\sum \dot{E}_{\text {loss }}=\sum \dot{E}_{t, \text { loss }}+\sum \dot{E}_{p, \text { loss }}+\sum \dot{E}_{b, \text { loss }}+\sum \dot{E}_{y, \text { loss }}$

$\varepsilon_{\text {system }}=\frac{\dot{W}_{\text {net }}}{\dot{E}_{\text {heat source }}}$

\subsection{System Advisor Model (SAM)}

The System Advisor Model (SAM), which is used to perform both technical and cost analyses of projects on generation of power from renewable energy sources, is a free techno-economic software model. This software program, which was first released under the name of "Solar Advisor Model", was continued to be used in 2010 by taking the name "System Advisor Model" after its content was developed. SAM calculates the hourly system performance and energy cost by using the design parameters in the models to be made in the projects created to obtain power from renewable energy sources. To analyze system performance and the cost of the system, design parameters and meteorological datas known as Typical Meteorological Year (TMY3) with CSV extensions, which belong METEONORM firm, are used. The modules of SAM program used in this study are demonstrated in Table 1 [30]. 
Table 1. The modules of SAM program [30]

\begin{tabular}{|c|c|}
\hline $\begin{array}{l}\text { Modules of } \\
\text { program }\end{array}$ & Description \\
\hline $\begin{array}{l}\text { Locationand } \\
\text { resource }\end{array}$ & $\begin{array}{l}\text { This is the module that } \\
\text { meteorological datas and } \\
\text { geograpical datas are inputed to } \\
\text { SAM program }\end{array}$ \\
\hline $\begin{array}{l}\text { Heliostat } \\
\text { field }\end{array}$ & $\begin{array}{l}\text { This is the module that the } \\
\text { required area for heliostat and } \\
\text { the number of heliostat are } \\
\text { determined }\end{array}$ \\
\hline $\begin{array}{l}\text { Tower } \\
\text { receiver }\end{array}$ & $\begin{array}{l}\text { This is the module that height } \\
\text { and diameter of recevier and } \\
\text { chemical properties of molten } \\
\text { salt are determined. }\end{array}$ \\
\hline Power cycle & $\begin{array}{l}\text { This is the module that the } \\
\text { capacity of system and power } \\
\text { generated by system are } \\
\text { determined. }\end{array}$ \\
\hline $\begin{array}{l}\text { Thermal } \\
\text { storage }\end{array}$ & $\begin{array}{l}\text { This is the module that the } \\
\text { number of storage tank and } \\
\text { storage time are determined }\end{array}$ \\
\hline $\begin{array}{l}\text { Tower } \\
\text { system costs }\end{array}$ & $\begin{array}{l}\text { This is the module that cost of } \\
\text { system elements and cost of } \\
\text { overall system are calculated }\end{array}$ \\
\hline
\end{tabular}

\section{RESULTS AND DISCUSSION}

In this investigation, technical performance analyses and cost analyses of the solar tower system with the various capacites as $10 \mathrm{MW}$ and $20 \mathrm{MW}$ for Mut district of Mersin were performed. The solar tower systems with the capacities of $10 \mathrm{MW}$ and $20 \mathrm{MW}$ were designed by using SAM (System advisor Model) program and the layout plan of heliostats was obtained. The design parameters used in the analyses of SAM program are presented in Table 2. The technical datas of system acquired from SAM program were used to implement the thermodynamic analyses. And the results of solar tower systems with the capacities of $10 \mathrm{MW}$ and $20 \mathrm{MW}$ were compared.

Table 2. Design parameters of solar tower system [31]

\begin{tabular}{|l|r|}
\hline Parameters & Amount \\
\hline Width of heliostat & $12.3 \mathrm{~m}$ \\
\hline Width of heliostat & $9.75 \mathrm{~m}$ \\
\hline Receiver height & $6 \mathrm{~m}$ \\
\hline Diameter of receiver & $8 \mathrm{~m}$ \\
\hline The number of storage tank \\
\hline Storage of storage tank & 10 hours \\
\hline Input temperature of molten salt & $290^{\circ} \mathrm{C}$ \\
\hline Output temperature of molten salt & $565^{\circ} \mathrm{C}$ \\
\hline $\begin{array}{l}\text { Min temperature for operating the } \\
\text { system }\end{array}$ & $500^{\circ} \mathrm{C}$ \\
\hline Pressure of steam & $10 \mathrm{MPa}$ \\
\hline Pressure of condenser & $200 \mathrm{kPa}$ \\
\hline $\begin{array}{l}\text { Temperature of referance }(\text { dead } \\
\text { state) }\end{array}$ & $25{ }^{\circ} \mathrm{C}$ \\
\hline Pressure of referance $($ dead state $)$ & $100 \mathrm{kPa}$ \\
\hline Turbine efficiency & 0.87 \\
\hline Pump efficiency & 0.82 \\
\hline Optical efficiency & 0.92 \\
\hline Receiver efficiency & 0.83 \\
\hline Wind velocity & $5 \mathrm{~m} / \mathrm{s}$ \\
\hline
\end{tabular}

In order to obtain the main results, meteorological datas named Typical Meteorological Year (TMY3) in csv format, which belong METEONORM firm, are used. Figure 7 demonstrates the location information and weather data information of Mut district of Mersin.

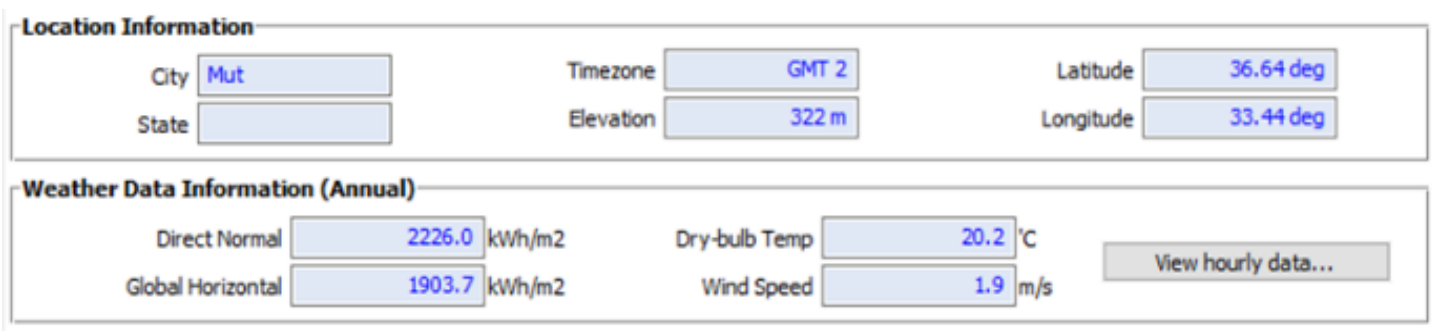

Figure 7. Location information and weather data information for Mut [28] 
After determining of design parameters shown in Table 2, the system analyses were done by SAM program and the tower heights of solar tower systems with the capacities of $10 \mathrm{MW}$ and $20 \mathrm{MW}$ were calculated as $51.11 \mathrm{~m}$ ve $71.11 \mathrm{~m}$, respectively. Furthermore, the numbers of required heliostat with the height of $9.75 \mathrm{~m}$ and the width of $12.3 \mathrm{~m}$ were determined as 580 and 1115 for the solar tower systems with the capacities of $10 \mathrm{MW}$ and $20 \mathrm{MW}$, respectively. The layout plans of heliostat composed by dividing the region azimuthal and radially are depicted in Figure 8.

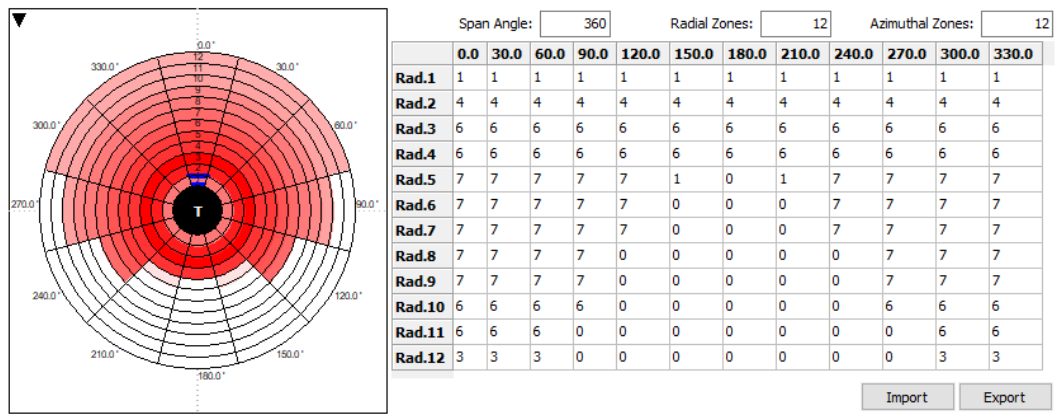

Layout plan of heliostat for the system having the capacity of $10 \mathrm{MW}$
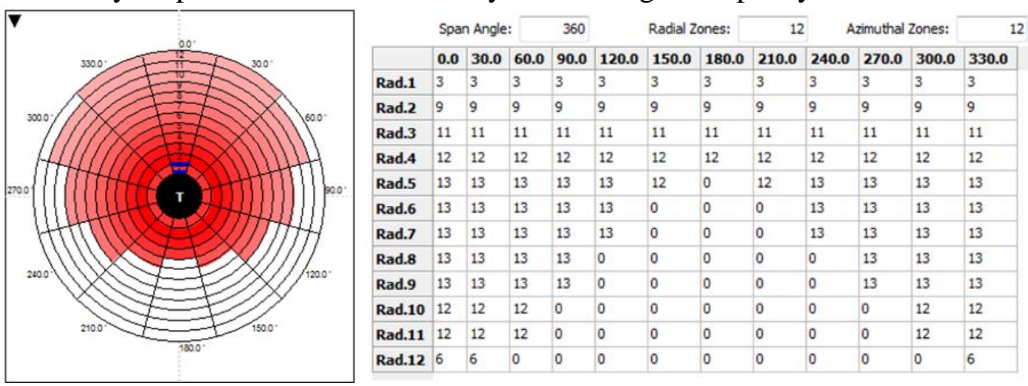

Layout plan of heliostat for the system having the capacity of $20 \mathrm{MW}$

Figure 8. Layout plans of heliostat

The net power generated by the solar tower systems with the capacities of 10MW and $20 \mathrm{MW}$ were theoretically determined as $9 \mathrm{MW}$ and 17 MW owing to the loss in the system, respectively. According to the layout plans of heliostat, the required area for this system with the capacity of $20 \mathrm{MW}$ was calculated as 149 decares and annual thermal energy was determined as $48.532 \mathrm{MWh}$ while the required area for this system with the capacity of $10 \mathrm{MW}$ and the annual thermal energy were assessed 84 decares and $24.272 \mathrm{MWh}$ by SAM program, respectively. Moreover, two hot tanks with 10 hours refill time and two cold tank with 10 hours refill time were used both the solar tower systems with the capacities of $10 \mathrm{MW}$ and $20 \mathrm{MW}$. The storage capacities of hot and cold tanks for the system designed for $10 \mathrm{MW}$ were obtained as $349.42 \mathrm{~m}^{3}$ and $815.32 \mathrm{~m}^{3}$ whereas the capacities of hot and cold tanks for the system designed for $20 \mathrm{MW}$ were calculated as $677.52 \mathrm{~m}^{3}$ and $1580.89 \mathrm{~m}^{3}$, respectively. The cost analyses of the system were performed by using SAM program and Table 3 indicates the details of cost analyses.

Table 3. The details of cost analyses for the solar tower system

\begin{tabular}{|l|c|c|}
\hline Exenditure & $\begin{array}{c}\text { Total cost for the } \\
\text { system with the } \\
\text { capcity of 10 } \\
\mathbf{M W} \mathbf{( \$ )}\end{array}$ & $\begin{array}{c}\text { Total cost for the } \\
\text { system with the } \\
\text { capcity of } \mathbf{2 0} \mathbf{~ M W} \\
\mathbf{( \$ )}\end{array}$ \\
\hline Heliostat & $\$ 12.144 .564,90$ & $\$ 23346879.08$ \\
\hline storage & $\$ 6.553 .398,06$ & $\$ 13106796.12$ \\
\hline Tower & $\$ 5.521 .462,60$ & $\$ 6817939.42$ \\
\hline Receiver & $\$ 16.057 .548,64$ & $\$ 22968114.05$ \\
\hline Others & $\$ 20.487 .278,56$ & $\$ 57297500.05$ \\
\hline Toplam & $\mathbf{\$ 6 0 . 7 6 4 . 2 5 2 , 7 6}$ & $\mathbf{\$ 1 2 3 5 3 7 2 2 8 . 7 2}$ \\
\hline
\end{tabular}


After the performance analysis and cost analysis were completed by SAM program, energy and exergy analyses were performed by using the equations mentioned above. According to the first law of thermodynamic, the pump work(Win) was assessed about $12.68 \mathrm{kj} / \mathrm{kg}$, turbine work (Wout) was calculated as $134543.21 \mathrm{kj} / \mathrm{kg}$ and the efficiency of the system was determined $44.32 \%$.

By using the second law of thermodynamic, the loss exergy was calculated as $33125,704 \mathrm{kj} / \mathrm{s}$. For the same dead state temperature and pressure, the exergy efficiency was determined as $42.75 \%$ based on the flow rate of the fluid used in the two systems with the capacity of 10 and $20 \mathrm{MW}$. Furthermore, both the exergy efficiencies of pump and turbine were determined as $\% 80.83$ ve $\% 75.38$, respectively.

\section{CONCLUSION}

In this study, the solar tower systems with the capacities of 10 and $20 \mathrm{MW}$ for Mut district of Mersin located at the coordinates of $33.4^{\circ} \mathrm{E} 36.7^{\circ}$ were designed by using SAM theoretically. The net power generated by the solar tower systems with the capacities of $10 \mathrm{MW}$ and $20 \mathrm{MW}$ were theoretically determined as $9 \mathrm{MW}$ and $17 \mathrm{MW}$ owing to the loss in the system, respectively. Moreover, The numbers of required heliostat with the height of $9.75 \mathrm{~m}$ and the width of $12.3 \mathrm{~m}$ were determined as 580 and 1115 for the solar tower systems with the capacities of $10 \mathrm{MW}$ and 20 MW, respectively. By using the solar tower systems with the capacity of $10 \mathrm{MW}$ and tower height of $51.11 \mathrm{~m}$, the obtained thermal energy was determined as $24.272 \mathrm{MWh}$ and the cost of this system was calculated as \$60764252,76. On the other hand, for the solar tower systems with the capacity of $20 \mathrm{MW}$ and tower height of ve 71.11 $\mathrm{m}$, the obtained thermal energy and cost of this mentioned system were assessed as $48.532 \mathrm{MWh}$ and $\$ 123537228.84$, respevtively.

According to the first and second law analyses, the energy efficiency in both systems is $44.32 \%$; while the exergy efficiency was calculated $42.75 \%$.

\section{REFERENCES}

1. Şenol, R., Üçgül, İ., Koyun, A., Acar, M., 2011. 10 MW'lık SDU Güneş Güç Kulesi Tesis Tasarımı. Gazi Üniversitesi MühendislikMimarlık Fakültesi Dergisi, 26(4), 813-821.

2. Üçgül, İ., Selbaş, R., Kızılkan, Ö., Şenol, R., Karakoç, H., 2003. Elektrik Enerjisi Üretiminde Güneş Kulesi Sisteminin Yapay Sinir Ağlarıyla Modellenmesi. Yenilenebilir Enerji Kaynakları Sempozyumu, 264-275.

3. Selbaş, R., Yakut, A.K., Şencan A., 2003. Güneş Kulesi Modeli ile Elektrik Enerjisi Üretimi için Bir Uygulama. Pamukkale Üniversitesi Mühendislik Bilimleri Dergisi, 9(2), 179-184.

4. Grasse, W., 1991. PHOEBUS: International 30 Mwe Solar Tower Plant. Solar Energy Materials, 24(1-4), 82-94.

5. Gottschalka, A., Ramamoorthia, U., 2018. Parametric Simulation and Economic Estimation of Thermal Energy-storage in Solar Power Tower. Materials Today: Proceedings 5, 1571-1577.

6. Hekim, M., 2017. Merkezi Alıcı Sistemli (MAS) Güneş Güç Santrali Birecik Uygulamas1. Yüksek Lisans Tezi, Hacettepe Üniversitesi, Ankara, 160.

7. Ağan, C., 2016. Güneş Güç Santrali ve Güneydoğu Anadolu Bölgesi için Bir Uygulama, Bitirme Çalışması. İstanbul Teknik Üniversitesi, İstanbul.

8. Adıyaman, G., 2018. Güneş Kulesi Alıcı Veriminin Sayısal Analizi. Gazi Üniveritesi, Fen Bilimleri Enstitüsü, Yüksek Lisans Tezi, Ankara, 140.

9. Papageorgiou, C.D., 2003. Efficiency of Solar Air Türbine Power Stations with Floating Solar Chimneys. http:/www.floathingsolarchimney.gr, Erişim Tarihi: a27.04.2019.

10. Xu, C., Wang, Z., Li, X., Sun, F., 2011. Energy and Exergy Analysis of Solar Power Tower Plants. Applied Thermal Engineering, 3904-3913.

11. Yang, M., Yang, X., Yang, X., Ding, J., 2010. Heat Transfer Enhancement and Performance of the Molten Salt Receiver of a Solar Power Tower. Applied Energy, 87 (9), 2808-2811.

12. Anonim. https://tr.climate- 
data.org/asya/tuerkiye/mersin/mut1865a6/, Erişim Tarihi: 20 Şubat 2021.

13. Anonim, http://www.enerjiatlasi.com/gunesenerjisiharitasi/mersin, Erişim Tarihi: 24 Mart 2019.

14. Karaman, R., 2016. Kombine Organik Rankine ve Kompresörlü Soğutma Çevriminin Termodinamik Analizi. Süleyman Demirel Üniversitesi, Fen Bilimleri Enstitüsü, Yüksek Lisans Tezi, Isparta, 98.

15. Schlaich, J., 2002. The Solar chimney, http:/www.sbp.de, Erişim Tarihi: 21 Şubat 2019.

16. www.watermill.com, Erişim Tarihi: 22 Şubat 2019.

17.Pişirir, O.M., 2014. Güneş Güç Kuleleri için Endüstriyel Pc Tabanlı Heliostat Kontrolü. Süleyman Demirel Üniversitesi, Fen Bilimleri Enstitüsü, Yüksek Lisans Tezi, Isparta, 99.

18. https://www.powertechnology.com/projects/aurora-solar-energyproject/, Erişim Tarihi: 24 Şubat 2019.

19. Özcan, A.K., 2005. Yoğunlaştırılmış Güneş Enerjisi ile Metal Ergitme. Karadeniz Teknik Üniversitesi, Fen Bilimleri Enstitüsü, Yüksek Lisans Tezi, Trabzon, 112.

20. Cauble, A., 2013. Brightsource's Heliostat Technology. 24 Mart 2019 tarihinde http://www.brightsourceenergy.com/brightsour ce\%E2\%80\%99s-

heliostattechnology\#.XOqgi4gzbIU, Erişim Tarihi: 26 Şubat 2019.

21. https://www.sustainabilitymatters.net.au/conten t/energy/news/csiro-s-heliostat-systems-to-bedeployed-in-china-712665658, Erişim Tarihi: 24 Şubat 2019.

22. Metin, İ., 2006. Elektrik Enerjisi Üretiminde Kullanılan Güneş Kulesi İçindeki Doğal Konveksiyonun Sayısal Olarak İncelenmesi. Gazi Üniversitesi, Fen Bilimleri Enstitüsü, Yüksek Lisans Tezi, Ankara, 10-14.

23. Çevik, M., 2018. Akdeniz Bölgesinde Kurulacak Olan Güneş Kulesinin Enerji ve Ekserji Analizi. İskenderun Teknik Üniversitesi, Mühendislik ve Fen Bilimleri Enstitüsü, Yüksek Lisans Tezi, İskenderun, 83.

24. Şenol, R., 2009. Güneş Kulelerinden Elektrik Enerjisi Üretiminin Araştırılması ve Optimizasyonu. Süleyman Demirel
Üniversitesi, Fen Bilimleri Enstitüsü, Doktora Tezi, Isparta, 223.

25. Tiryaki, G., 2017. Energy and Exergy Analysis and Performance Optimization of a Solar Power Tower System. Yildırım Beyazit Üniversitesi, Fen Bilimleri Enstitüsü, Yüksek Lisans Tezi, Ankara, 118.

26. Çengel, Y.A., Boles M.A., 1996. Mühendislik Yaklaşımıyla Termodinamik. (A. Pınarbaşı, Çev.) Literatür Yayıncılık, 978.

27. Gürlek, N.A., 2016. Organik Rankine Sistemi ve Türbininin Tasarımı. İstanbul Teknik Üniversitesi, Fen Bilimleri Enstitüsü, Yüksek Lisans Tezi, 91.

28. Yağlı, H., Koç, A., Koç, Y., Mumcu, A.G., 2014. Güneş Kulesinin Deniz Üzerinde Tasarımı ve Ekserji Analizi. ISITES'14, 906-915.

29. NREL, 2013, System Advisor Model (SAM) Version 2013.1.15 Manual.

30. Şanlı, B., Dilsel, T.E., Çalık, A., 2019. Design and Cost Analysis of Solar Tower with the Capacity of $20 \mathrm{mw}$ in Mut District of Mersin Province by Using Sam Program, $2^{\text {nd }}$ Cilicia International Symposium on Engineering and Technology. 